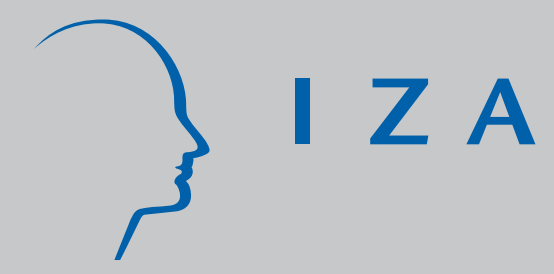

IZA DP No. 1947

Rates of Return to Degrees across British Regions

Nigel C. O'Leary

Peter J. Sloane

J anuary 2006 


\title{
Rates of Return to Degrees across British Regions
}

\author{
Nigel C. O'Leary \\ WELMERC, University of Wales Swansea \\ Peter J. Sloane \\ WELMERC, University of Wales Swansea \\ and IZA Bonn
}
Discussion Paper No. 1947
January 2006

\author{
IZA \\ P.O. Box 7240 \\ 53072 Bonn \\ Germany \\ Phone: +49-228-3894-0 \\ Fax: +49-228-3894-180 \\ Email: iza@iza.org
}

\begin{abstract}
Any opinions expressed here are those of the author(s) and not those of the institute. Research disseminated by IZA may include views on policy, but the institute itself takes no institutional policy positions.
\end{abstract}

The Institute for the Study of Labor (IZA) in Bonn is a local and virtual international research center and a place of communication between science, politics and business. IZA is an independent nonprofit company supported by Deutsche Post World Net. The center is associated with the University of Bonn and offers a stimulating research environment through its research networks, research support, and visitors and doctoral programs. IZA engages in (i) original and internationally competitive research in all fields of labor economics, (ii) development of policy concepts, and (iii) dissemination of research results and concepts to the interested public.

IZA Discussion Papers often represent preliminary work and are circulated to encourage discussion. Citation of such a paper should account for its provisional character. A revised version may be available directly from the author. 


\section{ABSTRACT \\ Rates of Return to Degrees across British Regions ${ }^{*}$}

Earlier papers have found considerable heterogeneity in the returns to degrees in relation to subjects of study, degree classification and higher education institution. In this paper we examine heterogeneity of returns across British regions using the Labour Force Survey. We find substantial variations in the financial rewards available to graduates across regions with much higher returns in London and the South East than elsewhere, although adjusting for regional differences in the cost-of-living narrows such differences considerably. Decompositional analysis, after controlling for regional differences in both occupational and industrial structures, suggests that coefficient effects dominate composition effects, consistent with agglomeration effects being important. These results have implications for the recent changes to student funding in England, Scotland and Wales.

JEL Classification: $\quad$ A22, A23, I21, J31, R1

Keywords: $\quad$ education, degree, rates of return, regions

Corresponding author:

Nigel C. O'Leary

WELMERC

Economics Department

James Callaghan Building

University of Wales Swansea

Singleton Park

Swansea SA2 8PP

UK

Email: n.c.oleary@swan.ac.uk

\footnotetext{
* Material from the Labour Force Survey is Crown Copyright: it has been made available by the Office for National Statistics (ONS) through The Data Archive and has been used by permission. All views expressed in this work are entirely those of the authors and not those of either the ONS nor the UK Data Archive.
} 


\section{Introduction}

The recommendations of the Dearing Commission (1997) signalled a dramatic shift in focus for the funding of students in higher education. Although 'top-up loans' were still available (see DES, 1988), students were now expected to make a contribution towards their tuition fees. In turn, in the White Paper The Future of Higher Education (DfES, 2003) the Government announced its intention to introduce, from 2006, a new Graduate Contribution Scheme under which universities would be allowed to charge annual tuition fees of up to $£ 3,000$, although payment by students would be deferred until after they had graduated. ${ }^{1}$ More so than ever, participation in higher education is being seen as a financial decision, with substantial investment costs incurred by students (and their sponsors) being set against improved labour market opportunities post graduation. Indeed, the Department of Education and Skills had calculated the lifetime earnings differential of graduates over non-graduates to be as much as $£ 400,000$ (see Greenaway and Haynes, 2003). ${ }^{2}$

Moreover, such opportunities will be heavily influenced by a number of factors related to personal characteristics, the nature and location of degree programmes and the state of the economy, and there is a growing body of empirical evidence highlighting the variable returns that are available to graduates. Amongst others, Blundell et al. (2000), Walker and Zhu (2003) and O'Leary and Sloane (2005) have found substantial heterogeneity in the returns across subject of study. Battu, Belfield and Sloane (1999) also found that class of first degree had a significant effect on graduate earnings up to eleven years after graduation. Similarly, those graduating from a long-established university earned between 8 and $11 \%$ more than those graduating from universities which were former polytechnics. Likewise, Elias and Purcell (2004) found that graduates are assimilated into appropriate jobs within the labour market at different rates, depending upon the type of degree and degree classification among other factors.

One area that has not attracted any attention is how rewards available to graduates are influenced by where they choose to work. Once students have selected a degree course at a

\footnotetext{
${ }^{1}$ Payments after graduation would be through the tax system, linked to ability to pay, with the threshold at which graduates would have to start repaying their fee contribution and maintenance loan fixed at $£ 15,000$.

${ }^{2}$ More recent research has suggested that this figure of $£ 400,000$ somewhat overestimated the additional career earnings a graduate could be expected to earn. Based on regression analysis, O'Leary and Sloane (2005) estimate that a representative male graduate would enjoy a $£ 141,539$ lifetime earnings advantage and a female graduate would enjoy a $£ 157,982$ advantage. These figures are more in line with a figure of $£ 120,000$ referred to in a recent Hansard Report of 8 June 2005 by the Minister of Higher Education in response to a parliamentary question arising from the above study.
} 
given institution and have graduated with a certain class of degree, these factors then become immutable, but where they gain employment will also exert a substantial influence over their earnings potential. To the extent that previous research has focussed upon providing information to potential students before they go to university, the analysis in this paper will be relevant to decision-making in the transitionary period between education and labour market engagement, through the calculation of the private rates of return that are available to university graduates across the standard regions of Great Britain. Implications for policymakers regarding the changes in annual tuition fees, which differ in England, Scotland and Wales are drawn in the conclusions.

\section{Methodology}

Consider the following relationship for any given individual living in region $\mathrm{R}$, whose highest educational attainment is either two or more A-Levels ${ }^{3}$ (denoted as a group A individual) or a degree (group D).

$$
\begin{aligned}
& \operatorname{Ln} Y^{A}=\alpha^{A}+\sum_{R=1}^{11} \beta_{R}^{A} A g e_{R}+\sum_{R=1}^{11} \gamma_{R}^{A} A g e_{R}^{2}+\delta^{A} X+\varepsilon^{A} \\
& \operatorname{Ln} Y^{D}=\alpha^{D}+\sum_{R=1}^{11} \beta_{R}^{D} A g e_{R}+\sum_{R=1}^{11} \gamma_{R}^{D} A g e_{R}^{2}+\delta^{D} X+\varepsilon^{D}
\end{aligned}
$$

where $\mathrm{Y}$ denotes net hourly earnings (expressed in constant prices), Age is the age in years of the respondent, $\mathrm{X}$ is a vector of characteristics known to influence net hourly earnings (but which are not affected by educational attainment), $\alpha$ is a constant, $\beta, \gamma$ and $\delta$ are conformable coefficient vectors and $\varepsilon$ is a regression disturbance term.

Assuming a representative individual with two or more A-Levels, predicted annual earnings (in constant prices) in region $\mathrm{R}$ at age $\mathrm{i}$ will be

$$
\hat{Y}_{R i}^{A}=\exp \left(\hat{\alpha}^{A}+\sum_{R=1}^{11} \phi_{R} \hat{\beta}_{R i}^{A} A g e_{R i}+\sum_{R=1}^{11} \phi_{R} \hat{\gamma}_{R i}^{A} A g e_{R i}^{2}+\hat{\delta}^{A} \bar{X}\right) \cdot h \text { ours }
$$

\footnotetext{
${ }^{3}$ A conventional approach to measuring the returns to degrees is to base estimates relative to those who could have pursued further education but chose not to do so. This comparator role is filled by those individuals who have gained two or more A-Levels.
} 
where a hat signifies a predicted value, $\phi$ denotes a dummy variable that takes a value of 1 if the individual is observed in region $\mathrm{R}$ (and 0 otherwise), $\bar{X}$ denotes a fixed set of characteristics that define the representative individual and hours denotes the annual hours this person works. Likewise, we can define the predicted annual earnings for the same representative individual in region $\mathrm{R}$ at age $\mathrm{i}$ but whose highest educational qualification is a degree as

$$
\hat{Y}_{R i}^{D}=\exp \left(\hat{\alpha}^{D}+\sum_{R=1}^{11} \phi_{R} \hat{\beta}_{R i}^{D} A g e_{R i}+\sum_{R=1}^{11} \phi_{R} \hat{\gamma}_{R i}^{D} A g e_{R i}^{2}+\hat{\delta}^{D} \bar{X}\right) \cdot h \text { hours }
$$

Assume that the individual with two or more A-Levels leaves school and enters the labour market at the age of 18 and that the individual with a degree completes their education at the age of 21 . With continuous employment until retirement (at the age of 65 for men and 60 for women), this will imply that the additional career earnings (ACE) of the degree holder over the holder of two or more A-Levels in region $\mathrm{R}$ will be

$$
A C E=\sum_{i=21}^{64 / 59}\left(\hat{Y}_{R i}^{D}-\hat{Y}_{R i}^{A}\right)
$$

For the degree holder, the cost of acquiring these additional career earnings can be measured in terms of direct costs (in the form of tuition fees) and indirect costs (in terms of forgone earnings). Thus,

$$
\text { Costs }=\text { fees }+\sum_{i=18}^{20} \hat{Y}_{R i}^{A}
$$

From this we can calculate the private rate of return on a degree for a representative individual in region $\mathrm{R}$ as the internal discount rate that equates the discounted increment to additional career earnings to the cost of acquiring a degree. ${ }^{4}$

\footnotetext{
${ }^{4}$ Weale (1993) provides a good discussion of the likely biases that may arise in the calculation of both private and social rates of return. However, given the comparison group of $2+$ A-Level holders used in this analysis and the fact that the focus is upon private returns, the only issue which may be relevant arises because of our assumption of continuous employment. Thus, if employment prospects are enhanced by a degree the true benefit of gaining such a qualification may be understated.
} 


\section{Data}

The data used in this analysis come from the Labour Force Survey (LFS), a large-scale survey conducted by the Office for National Statistics (ONS). Switched from an annual to a quarterly basis in 1992, it aims to produce a sample of approximately 60,000 responding households in Great Britain every quarter. Over the course of the survey respondents are interviewed on five separate occasions, commencing in the quarter they enter the survey and then once more in each of the next subsequent four quarters. Following their fifth interview respondents are replaced by a new cohort. This rotating sample design means that within any one quarter approximately one-fifth of all respondents are being interviewed for the first time, one-fifth for the second time etc., all the way up to the fifth who are being interviewed for the final time. There is, therefore, an eighty per cent overlap of respondents from any one quarter to the next. To avoid any possible double-counting we ensure that individuals are only picked up once during their participation within the LFS. This is done by selecting respondents only after they have provided earnings information. ${ }^{5}$

The data used run from the Spring of 2000 to the Winter of 2004. The end date was chosen as the most recently available year of data and the start point was chosen to provide a sufficiently large sample for the detailed analysis that follows. By pooling the separate quarters and after selecting only university graduates for whom there was no missing information, there were over 9,000 males and 8,600 females of working age remaining who had hourly earnings data available.

\section{Results}

As background to the discussion, the distribution of graduates across the Government Office Regions and split by gender is shown in Table $1 .{ }^{6}$ With reference to the regional distribution of the total workforce, the table also allows an inference to be drawn about the representation

\footnotetext{
${ }^{5}$ Since Spring 1997, respondents to the LFS are asked about their earnings during their first (wave 1) and final (wave 5) interviews. In the analysis conducted here, we select only wave 1 respondents.

${ }^{6}$ Graduates are defined as those who possess a university degree and will include those whose highest educational qualification is either a first degree or a higher degree. This classification is maintained in the rate of return calculations that follow and is adopted to account for any possible ability bias that might occur by concentrating upon undergraduate degree holders only. The reasoning behind this is that if the more able students go on to pursue postgraduate studies, excluding them would truncate the ability distribution and provide biased results. To counter this, all degree holders are retained and a dummy variable included denoting the possession of a higher degree. As it turns out, there is no evidence to support the hypothesis of the ability distribution being truncated and the results are unaffected by whether higher degree holders are included or not. Meanwhile, region is taken to denote region of work as opposed to the region where a graduate lives. Again, such a definition is maintained in the rate of return calculations that follow.
} 
of graduates within regions. Thus, a ratio of the share of graduate employment to total employment in a region greater than unity suggests an over-representation of graduates relative to what we might expect on the basis of the size of the regional labour market and a ratio less than unity an under-representation.

Clearly evident from Table 1 is the fact that there is a clustering of graduate employment in London and the South East, where for example $20.4 \%$ and $14.7 \%$ of all male graduates work respectively. Given that just 11.8\% (London) and 13.2\% (South East) of the male workforce are to be found in these regions, the ratios of graduate to total employment are 1.72 and 1.11 respectively. Such figures are indicative of graduate over-representation in numerical terms in these areas - a phenomenon not repeated in any of the other regions. At the other extreme is the North East, which has $4.0 \%$ of the male workforce and yet only $3.1 \%$ of male graduates. ${ }^{7}$ Likewise for women, a very similar pattern is repeated.

The private returns available to graduates relative to those with $2+$ A-Levels in the West Midlands are shown in Table 2.,9 There are substantial variations in the financial rewards available to graduates across regions, with far greater benefits arising from employment in the South East and London than in any other region. For example, male graduates can expect to see an annual return on their investment in a university education (in terms of foregone earnings and tuition costs) of $4.1 \%$ in Wales at one extreme and of $20.7 \%$ in London at the other extreme. ${ }^{10}$ To give an indication of the additional nominal lifetime earnings that such

\footnotetext{
${ }^{7}$ It should be noted that such findings are not merely driven by labour market size. In particular, Scotland has the third highest concentration of male graduates in a labour market that is comparable in size to Yorkshire \& Humberside and the South West, and yet these latter two regions have a far lower representation of male graduates. Likewise, the male workforce in Wales exceeds only that in the North East but has a graduate representation on a par with a number of much larger regions.

${ }^{8}$ All returns for graduates are calculated from the same region so as to provide a common benchmark. The West Midlands was chosen as it fits the criterion of a representative region on a number of grounds: average earnings in the region are at the median of the distribution of earnings across all regions; the magnitude of its underrepresentation of graduates in its workforce is similar to that in many other regions; the size of the local labour market is reasonably large; the cost-of-living in the region is representative of the cost-of-living in the majority of other regions outside of London and the South East. It should be remembered, though, that the choice of the West Midlands is still arbitrary and any other region could have been selected. These returns are calculated for a representative individual, details of which are given in the notes to Table 2, and are based upon a 'typical' 3-year degree course. For this reason, holder of degrees in medicine, dentistry and languages are all excluded as such degree programmes will typically have a duration in excess of three years. Similarly, holders of degreeequivalent qualifications (including HNC/HNDs, teaching and nursing diplomas, and NVQs above level 3) have also been excluded as such courses will rarely fit the typical 3-year course offered by universities.

${ }^{9}$ The variables used in the rate of return calculations are described in Appendix Table 2.

${ }^{10}$ The rates of return calculated in Table 2 are based upon the assumption that students do not work during the course of their studies. As such, if students have some sort of paid employment at the same time as they are studying, the implied annual rate of return to their increased career earnings will increase as the costs of
} 
returns represent, the figure for Wales is generated from additional career earnings of $£ 118,128$ and for London, $£ 410,486$. $^{11,12}$

The regional distribution of real earnings looks very different from that of nominal earnings. Using regional price data published by the Office for National Statistics, it is possible to deflate nominal earnings to arrive at a real earnings series. ${ }^{13}$ Regions with a higher cost-ofliving measured relative to the UK average will have real earnings in excess of nominal earnings and vice versa. Thus, real earnings are lower than nominal earnings in the Eastern region, the South West, the South East and London and higher in the remaining regions. So, for example, the previously noted nominal career earnings advantage of $£ 410,486$ that male graduates in London enjoy translates into a reduced $£ 293,370$ real earnings advantage, while the nominal career earnings boost of $£ 118,128$ for male graduates in Wales equates to a higher real figure of $£ 164,116 .^{14}$

The rates of return implied by such real earnings remain much higher in London (14.4\%) and to a lesser extent the South East $(8.1 \%)$ than elsewhere, but more generally there is a narrowing of regional rate of return differentials. Indeed, the percentage point difference covering real returns across all regions has fallen from 16.6 percentage points to 10.3

obtaining these (in terms of foregone earnings) will have fallen. For example, assuming that a student works for 16 hours per week at the national minimum wage for 18-21 year olds of $£ 4.25$ (October 2005) for 42 weeks of the year, the calculated annual returns to a degree for men in Wales and London would increase to 5.2\% and $29.9 \%$ respectively. It is likely that the returns reported in Table 2 will represent a lower bound to the returns available to graduates as some degree of part-time employment is becoming increasingly more important for university students.

${ }^{11}$ Although annual rates of return are derived from additional career earnings, such earnings are not presented in Table 2 as it would be misleading to make a direct comparison between additional earnings in different regions as these are allowed to accrue to graduates at different rates across regions. As already shown in equations (1) and (2) in section 2, the age-earnings profiles of workers (both graduates and non-graduates) are estimated separately for each region. Thus, it is not only how much more a graduate earns that is important, but also at what time in their career they earn it.

${ }^{12}$ It should be borne in mind that the estimated return of $5.4 \%$ for male graduates in Scotland is calculated on the basis of a four year degree course and not the three assumed for the regions of England and Wales. Some students in Scotland will, however, complete an ordinary degree in three years.

${ }^{13}$ ONS produces two regional price series, one which excludes housing price differentials and the other which includes them. Both of these are presented in Appendix Table 1. In the current analysis, it is the regional deflator which includes housing cost differences that is used to construct real earnings. Using the alternative series to deflate nominal earnings gives results bounded between the two (nominal and real) sets reported in Table 2. As a consistent series is not available for all years in our pooled sample, figures for 2004 are used to deflate nominal earnings in all years. For information on how the regional price series is constructed see Wingfield, Fenwick and Smith (2005). As respondents do not necessarily work and live in the same region, the deflator used to calculate real earnings is based upon region of residence and not region of work.

${ }^{14}$ In addition to providing the limits of nominal graduate returns for men, London and Wales also represent the highest and lowest cost regions. As such, the cost of living in London is 9.7 per cent above the UK average while that in Wales is 6.9 per cent below. See Appendix Table 1. 
percentage points. ${ }^{15}$ The lowest return is no longer offered to men in Wales, though, but rather to those in the South West, where a cost-of-living above the UK average (and lower than only London and the South East) has led to a dramatic decline in real returns. The South West and the West Midlands stand apart in the paucity of returns offered. The returns available in the remaining regions (excluding London and the South East) are focussed in a relatively narrow band, ranging from $6.0 \%$ (Yorkshire \& Humberside) to $6.7 \%$ (East Midlands and North West). ${ }^{16}$

For women, London (22.2\%), the South East (11.4\%) and the Eastern region (11.0\%) again offer a nominal earnings advantage for graduates in excess of what is available elsewhere, particularly so in the case of London. Outside of these three regions, the spread of returns is concentrated in a range between $6.5 \%$ (South West) and $8.8 \%$ (North West), although there is no apparent correlation between the regional performance of men and women outside of the south east of England. For example, the $8.7 \%$ nominal return to women in Yorkshire \& Humberside identifies this as a strong performing region for female graduates; while for men the nominal rate of $4.2 \%$ represents one of lowest returns available. Likewise, the figure of $6.5 \%$ reported for women in the South West represents the lowest nominal return of all regions, and yet the comparable position of men in the region was much more favourable. However, affirming the fact that women have more to gain from investing in a university education than do their male counterparts (see O'Leary and Sloane, 2005), the annual returns for women are in general well in excess of the comparable regional returns for men.

The pattern of real earnings advantage for female graduates relative to nominal earnings advantage exhibits many of the same trends highlighted for men. So while London emerges as the dominant region, with a female graduate here receiving a substantial $15.6 \%$ real return on her university investment, this figure is nearly seven percentage points less than the

\footnotetext{
${ }^{15}$ Even excluding London, there is a fall in the spread of returns across regions from 6.5 percentage points to 4.0 percentage points.

${ }^{16}$ While there will not always be a correlation between the region in which a person is employed and the region of residence, the above results are largely unaffected by commuting patterns. When the analysis was repeated along the lines of region of residence as opposed to region of work, the qualitative nature of the results was unaffected and the same regional patterns were exhibited. Quantitatively, the results were also similar, with discrepancies in rate of return estimates being very slight. The one exception to this was the Eastern region, where approximately one fifth of the graduate stock out-commutes to work in London. Thus, rate of return estimates based upon region of residence were approximately 2 percentage points higher than when calculated upon the basis of region of residence.
} 
nominal return. Likewise, both the Eastern region and the South East experience a moderation in the returns available which sees their relative positions decline markedly.

All regional rates of return have been calculated on the basis of students paying annual tuition fees of $£ 3,000$, the maximum permissible top-up fee chargeable by universities under the government's current proposals. Arrangements for students in Wales and Scotland are likely to be different from those in England, however, in that the National Assembly and Parliament in these regions respectively intend to charge lower fees to domiciled students. In Wales, the proposal is to limit the fee payable by domiciled students attending a domestic institution to $£ 1,200$ per annum. In Scotland, the proposal is for all domiciled students attending a Scottish institution to have their annual fees paid by the Students Awards Agency for Scotland. Such arrangements will obviously increase the rates of return available to Welsh and Scottish students who study domestically. Although it is not possible to identify such students directly within the Labour Force Survey, the effect of these fee arrangements more generally within the student population would be to raise the private rate of return by 0.6 (1.3) percentage points for a male graduate in Wales (Scotland) and by 1.1 (2.8) percentage points for females. It should be remembered, though, that these figures represent increases in private rates of return but it is unclear what the social returns to the economies of either Wales or Scotland would be from such a programme. However, figures from 2003/04 (National Assembly for Wales Report 2603/2604) show that a greater proportion of Scottish domiciled students attended a Scottish higher education institution (83\%) than did Welsh domiciled students who attended a Welsh higher education institution (61\%). Likewise, a greater proportion (87\%) of Scottish domiciled students leaving a higher education institution worked in Scotland than did comparable Welsh domiciled students working in Wales (72\%). Thus, it would appear that the ability of Scotland to retain a greater part of its university-educated workforce than Wales would mean that any additional social benefits from this programme would be higher in Scotland than they were in Wales.

\section{The determinants of regional graduate performance}

While there is no readily available way of quantifying the determinants of regional rate of return differences, it is possible to attribute differences in an alternative (and related) measure of regional graduate success. This alternative indicator is average real (gross) hourly earnings. As such, mean real earnings for male graduates are highest in London and lowest in the West Midlands and the South West, the same pattern identified in the previous rate of return 
analysis. Likewise, mean real earnings for female graduates are bounded between those in London at one extreme and in the South West at the other.

The most obvious drivers of differences in average gross hourly earnings are occupational and industrial structure across regions. ${ }^{17}$ As such, Tables $3 \mathrm{a}$ and $3 \mathrm{~b}$ detail the occupational composition across regions for male and female graduates separately and Tables $4 \mathrm{a}$ and $4 \mathrm{~b}$ do the same along the lines of industrial structure. Concentrating firstly upon occupational structure, there is a far greater representation of graduates in the highest paying "Managers and Senior Officials" category in London than elsewhere. So, for example, while $33.1 \%$ of male graduates occupy this position in London, the comparable figures in the North East and Wales are far lower at $22.6 \%$ and $20.2 \%$ respectively. Indeed, it is for these two regions that the calculated Duncan Index is at its greatest (Table 3a, column 6), suggesting that the occupational structure in these regions is most dissimilar to that found in London. ${ }^{18}$ Meanwhile, the South East (30.2\%), the West Midlands (29.3\%) and the East Midlands (28.1\%) all have a regional representation of graduates in the highest hierarchy of occupations closer to that in London, and certainly in the case of the South East and West Midlands this results in the closest occupational distributions to the London region.

However, while London and the South East have both the highest concentration of senior occupations and real earnings, it does not appear that the more favourable occupational distribution is the prime cause of the real earnings advantage. For one, we have already noted the inferior occupational base in Wales and the North East and yet average real hourly earnings of $£ 16.14$ and $£ 16.61$ respectively are higher than in a number of other regions. Indeed, similar conclusions could also be drawn from a number of other comparisons. Further, there is no evidence of a substantial increase in regional earnings once occupational distributions have been brought in line with that of London. So, for example, if the occupational base of male graduates in the North East was the same as that found for male

\footnotetext{
${ }^{17}$ This is borne out of a priori expectations and inspection of the data and is also vindicated by the research of Blackaby and Manning (1990). In their examination of nominal earnings in the UK, regional cost-of-living differences and differences in the industrial and occupational base were found to be the major determinants of regional wage differentials between the South East of England and the rest of Great Britain. Thus, our examination of real earnings will concentrate upon regional differences in the mix of jobs across industrial and occupational dimensions. It should be noted, though, that such information is not included in the calculation of rates of return, as where graduates find themselves employed will be part of the return to education in itself.

${ }^{18}$ The Duncan index of dissimilarity (see Duncan and Duncan, 1955) is based upon absolute deviations in the percentage employed in each occupation and indicates the percentage of graduates in any region that would have to move between occupations to achieve distributional equality with London.
} 
graduates in London, mean real hourly earnings in the North East would rise from $£ 16.61$ to $£ 17.04$ (Table 3a, row 8). ${ }^{19}$ This absolute increase of $£ 0.43$ is the largest movement reported in Table $3 \mathrm{a}$ and yet does little to move average earnings up to the level experienced in London. More generally, the relativities between regions are little affected by this adjustment, such that a common occupational distribution across all regions reveals the same distinct pattern of real regional earnings.

Likewise for women, substantial differences exist between the occupational base of graduates in London and that in the other regions (see Table $3 \mathrm{~b}$ ). The proportion of the graduate workforce in managerial positions in London is also greater than in other regions. At 21.2\%, this is someway in excess of the next highest figure of $16.2 \%$ reported for the South East and certainly well above the figures of $11.4 \%$ and $12.1 \%$ recorded in Scotland and Wales respectively. As demonstrated for men, though, such occupational differences have little influence over mean real earnings levels. In absolute terms, the effect of aligning occupational distributions across regions would see average real earnings rise by between $£ 0.03$ in the North West and $£ 0.22$ in the Eastern region and Wales.

With regard to industrial structure, the most striking feature for both male (see Table 4a) and female graduates (see Table $4 \mathrm{~b}$ ) is the regional over-representation of Banking and Insurance Services in London (row 4, heading J,K) and the Public Sector in the North East and Wales (row 5, heading L-N). For men, Banking and Insurance Services provide the major source of employment in London, with $41.7 \%$ of graduate employees being found within this sector. Meanwhile, even though the Public Sector accounts for a quarter (25.8\%) of male graduate employment in London, its representation here is lower than the comparable proportion in any of the other regions. Indeed, in both Wales (46.2\%) and the North East (51.9\%), this sector accounts for approximately one out of every two graduate jobs and in all but a handful of regions employs at least one third of all male graduates. ${ }^{20}$ However, in spite of these obvious regional differences in industrial structures, a more equal distribution of industries in itself would do little to remove regional graduate pay differentials. Moreover, mean real

\footnotetext{
${ }^{19}$ To calculate average earnings, a random sample of graduates in the North East was selected such that there was an exact match in the proportion in each of the five broad occupations used in Table $3 \mathrm{a}$ with that found in London. To avoid any potential bias, the sample was redrawn 1,000 times and earnings averaged across all draws. The same procedure was repeated in each of the standard regions.

${ }^{20}$ Given the distinct patterns of industrial clustering across regions, it comes as no surprise to note that the Duncan index for all regions (measured relative to London) is higher than that calculated along the lines of occupation.
} 
earnings in Wales (-£0.19), Scotland (-£0.35) and the North East (-£0.83) would even fall. ${ }^{21}$ Elsewhere, any changes in average earnings levels are marginal, with the largest absolute increase of $£ 0.24$ in the Eastern region representing less than a $1.5 \%$ change.

For women, the distribution of graduates across industries exhibits a similar pattern to that already identified for men, although the Public Sector is now the dominant employer in all regions including London. In fact, although the proportion of female graduates in the Public Sector is lower in London than elsewhere, nearly one half of employees are to be found in this sector nevertheless. Elsewhere, this proportion rises to nearly three quarters in the North East $(72.0 \%)$ and Wales (73.5\%). In common with our previous findings, removal of such industrial imbalances would do little to equate average earnings across regions (see Table $4 \mathrm{~b}$, row 9). While aligning the industrial base in the South East and the Eastern region with London would see negligible increases in average real earnings of $£ 0.13$ and $£ 0.12$ respectively, elsewhere the effect of this procedure would be to marginally lower earnings. Thus, the net effect upon the regional distribution of average earnings is insignificant.

So while there are obvious regional differences in the occupations and industries within which graduates find themselves employed, these structural differences do not account for the average real earnings differentials between regions in any significant way. However, decomposition analysis, as initially formulated by Blinder (1973) and Oaxaca (1973), can help identify the origin of these differences. ${ }^{22}$ Thus, the extent to which differences in the average real earnings of graduates in London relative to graduates in other regions are attributable to identifiable characteristic differences (a composition effect) or the way in which these characteristics are rewarded in regional labour markets (a coefficient effect) is

\footnotetext{
${ }^{21}$ Given the wage premiums afforded to public sector workers in the UK (see Blackaby et al., 1996), public sector employment is seen as an important institution for holding up wage levels in many regions. Thus, the process of adjustment used above would reduce the number of relatively highly paid public sector workers and so have a detrimental effect upon average earnings levels.

${ }^{22}$ The decompositions results that are presented have been derived from the following model:

$\overline{\operatorname{LnE}}^{L}-\overline{\operatorname{LnE}}^{o}=\hat{\rho}^{L}\left(\bar{Z}^{L}-\bar{Z}^{o}\right)+\left(\hat{\rho}^{L}-\hat{\rho}^{o}\right) \bar{Z}^{o}$,

where $E$ denotes gross hourly earnings, $Z$ represents a vector of characteristics that determine earnings (described in Appendix Table 2), $\rho$ denotes a conformable vector of estimated rewards to these characteristics, a bar denotes a mean value, a hat denotes a coefficient estimate, and the superscripts $\mathrm{L}$ and $\mathrm{O}$ denote the London region and another comparison region respectively. The first term on the RHS will measure the extent to which differences in mean characteristics between regions explain the difference in average earnings and is labelled the composition effect. Meanwhile, the second term on the RHS will measure the extent to which differences in the way that these characteristics are rewarded across regions explain the difference in average earnings. This second term is labelled the coefficient effect.
} 
shown in Table $5 .{ }^{23}$ For both men and women, the substantial log point differences that exist in average real earnings are primarily attributable to a coefficient effect i.e. the way in which individual characteristics that determine earnings are rewarded differently between regions. Following Yun (2004), it is possible to further decompose the coefficient effect in the same way that the composition effect has also traditionally been decomposed. ${ }^{24}$ Such a procedure highlights the importance of the constant term in the underlying wage models. ${ }^{25}$ This would be consistent with the existence of an agglomeration effect in London, such that areas of employment density are associated with higher average labour productivity (see Ciccone, 2002 for UK evidence on this). However, these findings are also consistent with the views of Lucas (1988) and Moretti (2004), in that workers benefit from working in an environment in which educated workers congregate: thus, graduates are more productive when they are surrounded by other graduates. Such human capital spillovers appear to be more important in London than elsewhere in raising the productivity of graduates and subsequently accounting for their higher wages. ${ }^{26}$

Such a conclusion is reinforced by the findings of Table 6 , which presents regional rate of return estimates for graduates measured relative to holders of $2+$ A-Levels in the same region. Calculating nominal rates of return in this way will remove not only regional price differences but also fixed regional labour market effects that will cause all workers to receive a higher remuneration and not just graduates. As such, the returns available within London are moderated dramatically and are less than those for any other region. For men, this implies a return to graduates of just $1.5 \%$, less than half the rate available in the next lowest region (3.3\%, Yorkshire \& Humberside) and well below the median estimate of 5.7\%. Likewise for

\footnotetext{
${ }^{23}$ While Table 5 presents only summary results of the decomposition analysis, full results, including a list of control variables that were included, are given in Appendix Tables $3 \mathrm{a}$ (males) and $3 \mathrm{~b}$ (females).

${ }^{24}$ The approach of Yun (2004) allows the identification of the individual components on the coefficient effect by imposing a linear restriction of zero upon any set of dummy variables (or any single category dummy variable). While this provides a tractable way of circumventing the baseline problem highlighted by Jones (1983), it does not solve the scale problem associated with the inclusion of continuous variables. For this reason, the underlying specification used in the estimation of the regional wage equations was composed entirely of dummy variables.

${ }^{25}$ The constant term is the dominant element in all of the regional decompositions with the exception of London versus the East Midlands for male graduates. From Appendix Table 3a we can see that the difference on returns to the employment status dummy variable in this decomposition is substantially greater than for any other region. Why this should be the case is not clear. However, when the sample of graduates was restricted to fulltime workers only, this anomalous result disappeared and the constant term emerged as the dominant element in all decompositions. Indeed, the magnitude of the influence of the constant term and its relative effect increased markedly when the analysis excluded part-time workers.

${ }^{26}$ As noted by Moretti (2004), higher productivity in areas with a higher proportion of college graduates are offset by higher wage costs. If this were not the case, firms would have an incentive to relocate to areas where they could recruit a more productive workforce.
} 
women, the 3.5\% figure in London, the lowest of any regional return, is appreciably lower than the $6.5 \%$ median return. In a similar vein, the higher returns variously afforded to graduates in the South East and the Eastern region are no longer in evidence when measured to a regional baseline. For men, the returns in these regions are now on a par with the returns available elsewhere, while for women the returns are some way below what is available in the rest of the country. Thus, our earlier finding that graduate returns were higher in the south east of England can be attributed to local labour market buoyancy and more so in London than in the South East or the Eastern region.

\section{Conclusions}

There are substantial variations in the earnings benefits that accrue to university graduates across the regions of Great Britain. This is true for both male and female graduates. Indeed, the rate of return on nominal earnings in London is more than double the comparable rate found in any other region outside of the South East. Cost-of-living differences play an important role in accounting for the spread in the rates of return across regions and when account is taken of regional living cost disparities the variance in returns is dramatically reduced. While the return on real earnings in London is still well in excess of that found elsewhere, the majority of other regions exhibit a similar magnitude of returns. An exception to this is the South West, which emerges as the region with the lowest real rate of return for both male and female graduates and a return someway below what is experienced in other regions. An unfavourably high cost-of-living in the region is seen as the reason for this.

In comparison, the mix of jobs appears to have little impact upon the relative regional prospects of graduates. Even though there are marked differences across regions on the basis of occupation and industry, a homogeneous employment mix along such lines would do little to align the average regional earnings of graduates. Notwithstanding this, there is some evidence that the public sector is an important graduate employer in many regions outside of London. Such findings would be consistent with the view that productivity spillovers in areas of graduate concentration and the presence of agglomeration effects are the principal drivers of the favourable earnings position of the graduate workforce in London. However, it is not possible to assess the relative importance of these two influences vis-à-vis one another in this current analysis. 
The effect of reducing fees for students in Scotland and Wales relative to those in England is likely to increase the proportion of students domiciled in those countries who study there. If this is the case, more graduates may subsequently choose to remain in their home region after completing their studies. This lower outmigration would likely see a fall in the overall return to degrees as the returns available within Scotland and Wales remain lower than in many other regions. In real terms, though, any such fall is likely to be somewhat less. A similar effect could also occur in England for those students domiciled outside of London and the South East, with the increased cost of studying leading to more of them choosing a local university so that they can reside at home.

Furthermore, there is a word of caution for policy makers in Scotland and Wales. Reduced fees for home students will increase their private returns and yet the returns for such students, when house price and cost-of-living differentials are allowed for, are not out of line with the returns on real earnings found elsewhere in Great Britain. Nevertheless, these returns are still well below those available in London and hence it will still be an attractive destination for more mobile graduates who will have benefited from a cheaper education. If regional mobility does not decline, the subsidisation of fees in these regions is likely to have little additional benefits for the Scottish and Welsh economies. Given the greater cross-border migration from Wales than from Scotland, this is likely to be a more important consideration in Wales. 


\section{References}

Battu H., Belfield C. and Sloane P. (1999) "Overeducation Among Graduates: A Cohort View", Education Economics, vol. 7, pp. 21-38.

Blackaby D. and Manning D. (1990), "The North-South Divide: Questions of Existence and Stability", Economic Journal, vol. 100, pp. 519-527.

Blackaby D., Murphy P. and O'Leary N. (1996) "The Payment of Public Sector Workers in the UK: Reconciliation with North American Findings", Economics Letters, vol. 65, pp. 239243.

Blinder A. (1973) "Wage Discrimination: Reduced Form and Structural Estimates" Journal of Human Resources, vol. 8, pp. 438-455.

Blundell R., Dearden L., Goodman A. and Reed H. (2000) "The Returns to Higher Education in Britain: Evidence from a British Cohort", Economic Journal, vol. 110, pp. F82-F99.

Ciccone A. (2002) "Agglomeration Effects in Europe", European Economic Review, vol. 46, pp. 213-227.

Dearing Commission (1997) Higher Education in the Learning Society, HMSO: Great Britain.

DES (1988) Top-Up Loans for Students, Department of Education and Science, no. 520.

Department of Education and Skills (2003) The Future of Higher Education, HMSO, CM5735.

Duncan O. and Duncan B. (1955) "A Methodological Analysis of Segregation Indices", American Sociological Review, vol. 20, pp. 210-217.

Elias P. and Purcell K. (2004) "Is Mass Higher Education Working?: Evidence from the Labour Market Experiences of Recent Graduates", National Institute Economic Review, no. 190, pp. 60-74.

Greenaway D. and Haynes M. (2003) Funding Universities to Meet National and International Challenges, Nottingham University School of Economics Policy.

Jones F. (1983) "On Decomposing the Wage Gap: A Critical Comment on Blinder's Method", Journal of Human Resources, vol. 18, pp. 126-130.

Lucas R. (1988) "On the Mechanics of Economic Development", Journal of Monetary Economics, vol. 22, pp. 3-42.

Moretti E. (2004) "Workers' Education, Spillovers, and Productivity: Evidence from PlantLevel Production Functions", American Economic Review, vol. 94, pp. 656-690.

Oaxaca R. (1973) "Male-Female Wage Differentials in Urban Labor Markets", International Economic Review, vol. 14, pp. 693-709. 
O'Leary N. and Sloane P. (2005) "The Return to a University Education in Great Britain", National Institute Economic Review, no. 193, pp. 75-89.

Walker I. and Zhu Y. (2003) "Education, Earnings and Productivity: Recent UK Evidence", Labour Market Trends, March, pp. 145-152.

Weale M. (1993) "A Critical Analysis of Rate of Return Analysis", Economic Journal, vol. 103, pp. 729-737.

Wingfield D., Fenwick D. and Smith K. (2005) "Relative Regional Consumer Price Levels in 2004", Economic Trends, no. 615, pp 36-45.

Yun (2004) "Decomposing Differences in the First Moment", Economic Letters, vol. 82, pp. 275-280. 
Table 1

Share of Graduate Employment by Region: LFS 2001-2004 (Weighted)

\begin{tabular}{|l|r|r|r|r|r|r|}
\cline { 2 - 7 } \multicolumn{1}{c|}{} & \multicolumn{3}{c|}{ MEN } & \multicolumn{3}{c|}{ WOMEN } \\
\cline { 2 - 7 } \multicolumn{1}{c|}{$\begin{array}{c}\text { \% of } \\
\text { workforce }\end{array}$} & $\begin{array}{c}\text { \% of } \\
\text { graduates }\end{array}$ & \multicolumn{1}{c|}{ Ratio $^{+}$} & $\begin{array}{c}\text { \% of } \\
\text { workforce }\end{array}$ & $\begin{array}{c}\text { \% of } \\
\text { graduates }\end{array}$ & Ratio $^{+}$ \\
\hline North East & 4.0 & 3.1 & 0.78 & 4.3 & 3.2 & 0.74 \\
\hline Yorks \& Humber & 8.8 & 7.3 & 0.83 & 8.8 & 8.0 & 0.90 \\
\hline East Midlands & 7.2 & 5.8 & 0.81 & 7.2 & 6.0 & 0.83 \\
\hline Eastern & 9.2 & 8.0 & 0.86 & 9.5 & 8.5 & 0.89 \\
\hline London & 11.8 & 20.4 & 1.72 & 10.3 & 18.6 & 1.80 \\
\hline South East & 13.2 & 14.7 & 1.11 & 13.4 & 14.4 & 1.07 \\
\hline South West & 8.5 & 7.5 & 0.87 & 8.7 & 7.9 & 0.91 \\
\hline West Midlands & 9.1 & 7.7 & 0.84 & 8.9 & 7.5 & 0.84 \\
\hline North West & 14.3 & 12.9 & 0.90 & 14.5 & 12.4 & 0.86 \\
\hline Wales & 5.0 & 4.3 & 0.86 & 5.0 & 4.6 & 0.92 \\
\hline Scotland & 8.8 & 8.4 & 0.96 & 9.4 & 9.0 & 0.96 \\
\hline
\end{tabular}

Notes: ${ }^{+}$ratio of graduate employment to all other employees in a particular region. 
Table 2

Degree Returns Relative to 2+ A-Levels in the West Midlands:

LFS 2001-2004

\begin{tabular}{|l|r|r|r|r|}
\cline { 2 - 5 } \multicolumn{1}{c|}{} & \multicolumn{2}{c|}{ MEN } & \multicolumn{2}{c|}{ WOMEN } \\
\cline { 2 - 5 } \multicolumn{1}{c|}{} & $\begin{array}{c}\text { Nominal } \\
\text { (\%pa) }\end{array}$ & $\begin{array}{c}\text { Real } \\
\mathbf{( \% p a )}\end{array}$ & $\begin{array}{c}\text { Nominal } \\
\text { (\%pa) }\end{array}$ & $\begin{array}{c}\text { Real } \\
\text { (\%pa) }\end{array}$ \\
\hline North East & 4.8 & 6.3 & 8.2 & 9.9 \\
\hline Yorkshire \& Humberside & 4.2 & 6.0 & 8.7 & 10.5 \\
\hline East Midlands & 6.5 & 6.7 & 7.4 & 7.7 \\
\hline Eastern & 7.7 & 6.1 & 11.0 & 9.3 \\
\hline London & 20.7 & 14.4 & 22.2 & 15.6 \\
\hline South East & 11.6 & 8.1 & 11.4 & 7.9 \\
\hline South West & 6.0 & 4.1 & 6.5 & 4.9 \\
\hline West Midlands & 4.6 & 4.7 & 8.1 & 8.2 \\
\hline North West & 6.2 & 6.7 & 8.8 & 9.3 \\
\hline Wales & 4.1 & 6.1 & 7.2 & 9.4 \\
\hline Scotland & 5.3 & 6.4 & 8.0 & 9.5 \\
\hline
\end{tabular}

Notes: estimates based on a white married employee with an undergraduate degree (not Medicine, Dentistry or Languages) working full-time (37.5 hours per week) in 2004, with current employer for 5 or more years; graduates assumed to be in continuous employment from ages 21-59/64 (women/men); A-Level holders assumed to be in continuous employment from ages 18-59/64 (women/men); 3 year course of study with no employment income during period of study (4 year course in the case of Scotland); $£ 3,000$ annual tuition fees. 
Table 3a

Occupational Distribution (SOC2000) of Male Graduates by Region: LFS 2001-2004

\begin{tabular}{|c|c|c|c|c|c|c|c|c|c|c|c|}
\hline & NE & YH & EM & $\mathbf{E}$ & $\mathbf{L}$ & SE & SW & WM & NW & $\mathbf{W}$ & $\mathbf{S}$ \\
\hline Managers and senior officials & 22.6 & 24.0 & 28.1 & 26.1 & 33.1 & 30.2 & 25.3 & 29.3 & 26.2 & 20.2 & 26.9 \\
\hline Professional occupations & 49.4 & 46.7 & 42.4 & 46.3 & 34.4 & 46.5 & 46.3 & 42.3 & 43.2 & 50.5 & 44.9 \\
\hline Associate professional and technical & 15.9 & 16.4 & 18.4 & 16.7 & 22.0 & 13.4 & 17.7 & 16.3 & 18.2 & 16.9 & 17.7 \\
\hline Administrative and secretarial & 4.5 & 4.2 & 6.3 & 2.6 & 6.1 & 4.5 & 4.1 & 4.6 & 5.2 & 4.0 & 3.6 \\
\hline Other occupations & 7.6 & 8.7 & 4.8 & 8.2 & 4.4 & 5.6 & 6.7 & 7.6 & 7.2 & 8.3 & 7.0 \\
\hline Duncan Index (relative to SE) & 18.19 & 16.57 & 8.61 & 15.66 & 0.0 & 13.19 & 14.17 & 11.04 & 11.62 & 20.02 & 13.08 \\
\hline Mean gross real hourly earnings $(£)$ & 16.61 & 16.38 & 16.57 & 16.20 & \multirow{2}{*}{19.62} & 17.21 & 15.69 & 15.50 & 16.14 & 16.14 & 17.19 \\
\hline Mean gross real hourly earnings $(£)^{+}$ & 17.04 & 16.73 & 16.70 & 16.33 & & 17.19 & 15.88 & 15.61 & 16.40 & 16.44 & 17.25 \\
\hline
\end{tabular}

Note: ${ }^{+}$denotes an adjusted earnings series. See footnote 19.

Table 3b

Occupational Distribution (SOC2000) of Female Graduates by Region: LFS 2001-2004

\begin{tabular}{|c|c|c|c|c|c|c|c|c|c|c|c|}
\hline & NE & YH & EM & $\mathbf{E}$ & $\mathbf{L}$ & SE & SW & WM & NW & $\mathbf{W}$ & $\mathbf{S}$ \\
\hline Associate professional and technical & 26.4 & 24.0 & 23.0 & 22.7 & 27.5 & 20.8 & 23.4 & 22.2 & 24.2 & 23.1 & 27.7 \\
\hline Other occupations & 6.1 & 7.3 & 9.2 & 6.9 & 4.2 & 8.6 & 9.0 & 9.0 & 8.0 & 7.0 & 8.9 \\
\hline Duncan Index (relative to SE) & 10.78 & 11.58 & 14.78 & 14.64 & 0.0 & 15.72 & 13.76 & 13.36 & 13.02 & 15.49 & 13.60 \\
\hline Mean gross real hourly earnings (£) & 13.64 & 13.83 & 12.47 & 13.43 & 15.07 & 13.24 & 11.86 & 12.75 & 13.12 & 13.78 & 13.88 \\
\hline
\end{tabular}

Note: ${ }^{+}$denotes an adjusted earnings series. See footnote 19. 
Table 4a

Industrial Distribution (SIC92) of Male Graduates by Region: LFS 2001-2004

\begin{tabular}{|c|c|c|c|c|c|c|c|c|c|c|c|}
\hline & NE & YH & EM & $\mathbf{E}$ & $\mathbf{L}$ & SE & SW & WM & NW & $\mathbf{W}$ & $\mathbf{S}$ \\
\hline A-F: Agriculture/ Energy/Manufacturing/Construction & 19.8 & 21.8 & 29.0 & 25.8 & 14.1 & 24.5 & 21.6 & 28.5 & 28.3 & 21.2 & 25.6 \\
\hline I: Transport \& Comunications & 4.5 & 4.0 & 4.3 & 5.0 & 5.8 & 5.3 & 4.5 & 4.4 & 4.6 & 3.3 & 2.1 \\
\hline L-N: Public Admin/Education \& Health & 51.9 & 43.0 & 38.5 & 30.4 & 25.8 & 29.8 & 40.9 & 30.9 & 34.1 & 46.2 & 38.4 \\
\hline O-Q: Other Services & 3.5 & 4.5 & 3.9 & 6.5 & 7.1 & 3.2 & 3.7 & 6.8 & 4.7 & 8.1 & 4.4 \\
\hline Duncan Index (relative to SE) & 31.75 & 25.96 & 29.33 & 18.34 & 0.0 & 15.53 & 22.58 & 21.32 & 24.23 & 29.31 & 24.11 \\
\hline
\end{tabular}

Note: ${ }^{+}$denotes an adjusted earnings series. See footnote 19.

Table 4b

\section{Industrial Distribution (SIC92) of Female Graduates by Region: LFS 2001-2004}

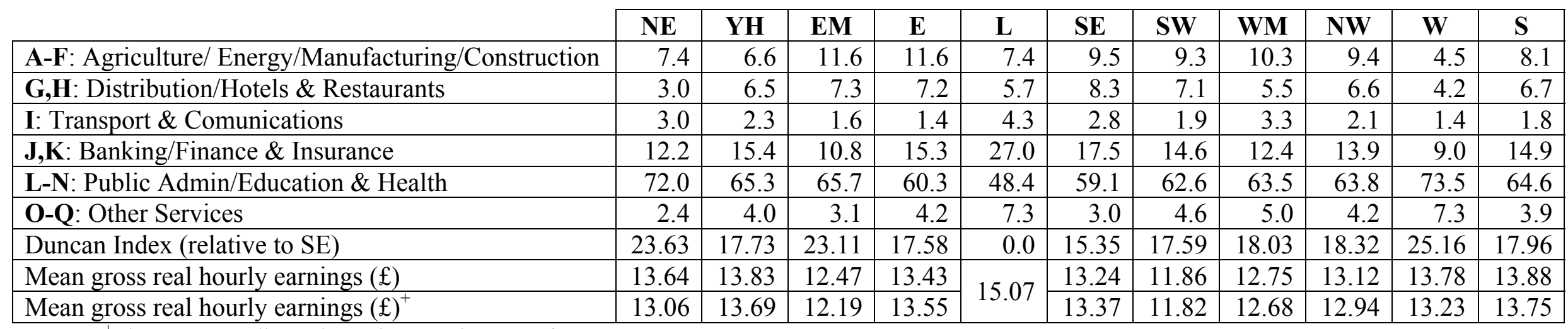

Note: ${ }^{+}$denotes an adjusted earnings series. See footnote 19. 
Table 5

Summary Log Point Decomposition of Regional Real Earnings Differential for Graduates Relative to London: LFS 2001-2004

\begin{tabular}{|c|c|c|c|c|c|c|c|c|}
\hline & \multicolumn{4}{|c|}{ MEN } & \multicolumn{4}{|c|}{ WOMEN } \\
\hline & $\begin{array}{l}\text { Earnings } \\
\text { Difference }\end{array}$ & $\begin{array}{l}\text { Composition } \\
\text { Effect }\end{array}$ & $\begin{array}{l}\text { Coefficient } \\
\text { Effect }\end{array}$ & Constant & $\begin{array}{l}\text { Earnings } \\
\text { Difference }\end{array}$ & $\begin{array}{c}\text { Composition } \\
\text { Effect }\end{array}$ & $\begin{array}{l}\text { Coefficient } \\
\text { Effect }\end{array}$ & Constant \\
\hline North East & 0.1355 & 0.0579 & 0.0776 & 0.1094 & 0.0769 & -0.0019 & 0.0811 & 0.1185 \\
\hline Yorkshire \& Humberside & 0.1718 & 0.0527 & 0.1191 & 0.1634 & 0.0837 & 0.0073 & 0.0764 & 0.1478 \\
\hline East Midlands & 0.1615 & 0.0437 & 0.1179 & -0.0285 & 0.1675 & 0.0189 & 0.1486 & 0.2706 \\
\hline Eastern & 0.1735 & 0.0343 & 0.1392 & 0.1343 & 0.1196 & -0.0158 & 0.1354 & 0.2380 \\
\hline South East & 0.1192 & -0.0037 & 0.1229 & 0.0923 & 0.1367 & -0.0280 & 0.1656 & 0.2054 \\
\hline South West & 0.1956 & 0.0216 & 0.1740 & 0.1030 & 0.2263 & 0.0191 & 0.2071 & 0.3296 \\
\hline West Midlands & 0.2082 & 0.0298 & 0.1784 & 0.1506 & 0.1594 & 0.0136 & 0.1458 & 0.1896 \\
\hline North West & 0.1681 & 0.0442 & 0.1239 & 0.1069 & 0.1170 & 0.0060 & 0.1110 & 0.1627 \\
\hline Wales & 0.1793 & 0.0660 & 0.1133 & 0.0992 & 0.0745 & 0.0017 & 0.0728 & 0.2402 \\
\hline Scotland & 0.1014 & 0.0136 & 0.0878 & 0.0830 & 0.0690 & -0.0015 & 0.0720 & 0.2635 \\
\hline
\end{tabular}


Table 6

Degree Returns Relative to 2+ A-Levels in Own Region: LFS 2001-2004

\begin{tabular}{|l|r|r|}
\cline { 2 - 3 } \multicolumn{1}{c|}{} & \multicolumn{2}{c|}{ Nominal (\%pa) } \\
\cline { 2 - 3 } \multicolumn{1}{c|}{} & \multicolumn{1}{c|}{ MEN } & WOMEN \\
\hline North East & 5.2 & 7.8 \\
\hline Yorkshire \& Humberside & 3.3 & 6.5 \\
\hline East Midlands & 7.5 & 6.3 \\
\hline Eastern & 5.0 & 5.0 \\
\hline London & 1.5 & 3.5 \\
\hline South East & 5.9 & 4.9 \\
\hline South West & 6.6 & 6.5 \\
\hline West Midlands & 4.6 & 8.1 \\
\hline North West & 6.5 & 6.7 \\
\hline Wales & 5.7 & 6.3 \\
\hline Scotland & 6.6 & 8.6 \\
\hline
\end{tabular}

Notes: see Table 2. 
Appendix Table 1

Average Regional Prices Relative to National Average Price (UK=100)

\begin{tabular}{|l|r|r|}
\cline { 2 - 3 } \multicolumn{1}{c|}{} & \multicolumn{1}{c|}{$\begin{array}{c}\text { Excluding } \\
\text { Housing Costs }\end{array}$} & $\begin{array}{c}\text { Including } \\
\text { Housing Costs }\end{array}$ \\
\hline North East & 96.1 & 94.2 \\
\hline Yorks/Humber & 95.9 & 94.2 \\
\hline East Midlands & 97.8 & 97.4 \\
\hline Eastern & 99.6 & 101.1 \\
\hline London & 107.1 & 109.7 \\
\hline South East & 101.6 & 105.3 \\
\hline South West & 100.0 & 101.3 \\
\hline West Midlands & 98.2 & 97.8 \\
\hline North West & 98.4 & 96.9 \\
\hline Wales & 96.5 & 93.1 \\
\hline Scotland & 98.0 & 94.5 \\
\hline
\end{tabular}




\section{Appendix Table 2}

Variable Definitions for Rate of Return and Decomposition Analyses

\begin{tabular}{|c|c|}
\hline Variable & Variable description \\
\hline Net earnings & $\begin{array}{l}\text { Net hourly earnings from employment in Jan } 2002 \text { prices. Net } \\
\text { hourly earnings are defined as actual net weekly earnings } \\
\text { deflated by usual weekly hours worked excluding unpaid } \\
\text { overtime. (R) }\end{array}$ \\
\hline Gross earnings & $\begin{array}{l}\text { The natural logarithm of gross hourly earnings from } \\
\text { employment in Jan } 2002 \text { prices. Gross hourly earnings are } \\
\text { defined as actual gross weekly earnings deflated by usual } \\
\text { weekly hours worked excluding unpaid overtime. (D) }\end{array}$ \\
\hline Age & $\begin{array}{l}\text { Age of respondent in years; entered in linear and quadratic } \\
\text { form. }(\mathbf{R})\end{array}$ \\
\hline Ageband & $\begin{array}{l}\text { Set of dummy variables (13) denoting the age of the respondent. } \\
\text { (D) }\end{array}$ \\
\hline Ethni & $\begin{array}{l}\text { Dummy variable indicating that the respondent is of an ethnic } \\
\text { origin other than white.(RD) }\end{array}$ \\
\hline Mari & $\begin{array}{l}\text { Set of dummy variables (3) denoting the marital status of the } \\
\text { respondent. (RD) }\end{array}$ \\
\hline Employ & $\begin{array}{l}\text { Dummy variable indicating that the respondent works on a part- } \\
\text { time basis. (RD) }\end{array}$ \\
\hline Job te & $\begin{array}{l}\text { Set of dummy variables (3) denoting the number of years the } \\
\text { respondent has been with their current employer. (RD) }\end{array}$ \\
\hline Higher degree & $\begin{array}{l}\text { Dummy variable indicating that the respondent has a higher } \\
\text { degree. (RD) }\end{array}$ \\
\hline Industry & $\begin{array}{l}\text { Set of dummy variables (6) denoting the industry in which the } \\
\text { respondent is employed. (D) }\end{array}$ \\
\hline Occupation & $\begin{array}{l}\text { Set of dummy variables (5) denoting the occupation in which } \\
\text { the respondent is employed. (D) }\end{array}$ \\
\hline Year of interview & $\begin{array}{l}\text { Set of dummy variables (5) denoting the year in which the } \\
\text { respondent completed their interview. (RD) }\end{array}$ \\
\hline
\end{tabular}

Note: (R) signifies a variable used only in the calculation of rates of return; (D) signifies a variable used only in the decomposition analysis; (RD) denotes a variable used in both analyses. 


\section{Appendix Table 3a}

Log Point Decomposition of Regional Real Earnings Differential for Male Graduates Relative to London: LFS 2001-2004

\begin{tabular}{|c|c|c|c|c|c|c|c|c|c|c|}
\hline & NE & YH & EM & $\mathbf{E}$ & SE & SW & WM & $\mathbf{N W}$ & $\mathbf{W}$ & $\mathbf{S}$ \\
\hline Mean earnings difference & 0.1355 & 0.1718 & 0.1615 & 0.1735 & 0.1192 & 0.1956 & 0.2082 & 0.1681 & 0.1793 & 0.1014 \\
\hline Characteristic effect & 0.0579 & 0.0527 & 0.0437 & 0.0343 & -0.0037 & 0.0216 & 0.0298 & 0.0442 & 0.0660 & 0.0136 \\
\hline Ethnic origin & -0.0000 & -0.0000 & -0.0000 & -0.0000 & -0.0000 & -0.0000 & -0.0000 & -0.0000 & -0.0001 & -0.0000 \\
\hline Employment status & 0.0003 & 0.0077 & 0.0053 & 0.0034 & 0.0012 & 0.0064 & 0.0018 & 0.0013 & 0.0019 & 0.0019 \\
\hline Higher degree & 0.0000 & -0.0009 & 0.0030 & 0.0001 & -0.0009 & -0.0010 & 0.0013 & 0.0010 & -0.0013 & -0.0004 \\
\hline Marital status & -0.0102 & -0.0097 & -0.0085 & -0.0083 & -0.0073 & -0.0137 & -0.0092 & -0.0072 & -0.0091 & -0.0088 \\
\hline Year of interview & -0.0003 & -0.0002 & -0.0005 & 0.0006 & 0.0004 & 0.0000 & -0.0002 & 0.0003 & -0.0003 & -0.0003 \\
\hline Job tenure & -0.0029 & -0.0025 & -0.0038 & -0.0030 & -0.0023 & -0.0056 & -0.0027 & -0.0035 & -0.0047 & -0.0051 \\
\hline Ageband & -0.0304 & -0.0283 & -0.0213 & -0.0117 & -0.0183 & -0.0282 & -0.0174 & -0.0139 & -0.0285 & -0.0324 \\
\hline Occupation & 0.0199 & 0.0224 & 0.0066 & 0.0142 & -0.0005 & 0.0128 & 0.0113 & 0.0164 & 0.0257 & 0.0109 \\
\hline Industry & 0.0815 & 0.0643 & 0.0630 & 0.0390 & 0.0237 & 0.0510 & 0.0448 & 0.0497 & 0.0823 & 0.0479 \\
\hline Coefficient effect & 0.0776 & 0.1191 & 0.1179 & 0.1392 & 0.1229 & 0.1740 & 0.1784 & 0.1239 & 0.1133 & 0.0878 \\
\hline Ethnic origin & -0.0557 & -0.0716 & 0.0495 & 0.0407 & -0.0058 & 0.0938 & -0.0118 & -0.0193 & 0.0428 & 0.0256 \\
\hline Employment status & 0.1290 & 0.1061 & 0.2013 & 0.0359 & 0.0643 & 0.0833 & 0.0665 & 0.0724 & 0.0934 & 0.1174 \\
\hline Higher degree & -0.0014 & -0.0027 & 0.0177 & -0.0124 & -0.0067 & -0.0016 & 0.0183 & 0.0131 & 0.0056 & 0.0014 \\
\hline Marital status & -0.0206 & -0.0224 & -0.0274 & -0.0057 & -0.0056 & -0.0413 & -0.0076 & 0.0005 & 0.0009 & -0.0336 \\
\hline Year of interview & 0.0090 & 0.0054 & 0.0154 & 0.0096 & 0.0104 & 0.0016 & 0.0114 & -0.0020 & 0.0140 & -0.0238 \\
\hline Job tenure & 0.0024 & 0.0004 & -0.0069 & 0.0010 & -0.0017 & -0.0063 & -0.0030 & -0.0041 & -0.0113 & -0.0176 \\
\hline Ageband & 0.0059 & 0.0036 & -0.0057 & 0.0002 & -0.0008 & 0.0033 & -0.0048 & 0.0006 & 0.0033 & -0.0012 \\
\hline Occupation & -0.0352 & -0.0489 & -0.0404 & -0.0598 & -0.0318 & -0.0120 & -0.0127 & -0.0261 & -0.0497 & -0.0306 \\
\hline Industry & -0.0652 & -0.0143 & -0.0572 & -0.0046 & 0.0083 & -0.0498 & -0.0285 & -0.0181 & -0.0852 & -0.0330 \\
\hline Constant & 0.1094 & 0.1634 & -0.0285 & 0.1343 & 0.0923 & 0.1030 & 0.1506 & 0.1069 & 0.0992 & 0.0830 \\
\hline
\end{tabular}




\section{Appendix Table 3b}

Log Point Decomposition of Regional Real Earnings Differential for Female Graduates Relative to London: LFS 2001-2004

\begin{tabular}{|c|c|c|c|c|c|c|c|c|c|c|}
\hline & $\mathbf{N E}$ & YH & EM & $\mathbf{E}$ & SE & SW & WM & NW & $\mathbf{W}$ & $\mathbf{S}$ \\
\hline Mean earnings difference & 0.0769 & 0.0837 & 0.1675 & 0.1196 & 0.1367 & 0.2263 & 0.1594 & 0.1170 & 0.0745 & 0.0690 \\
\hline Characteristic effect & -0.0019 & 0.0073 & 0.0189 & -0.0158 & -0.0280 & 0.0191 & 0.0136 & 0.0060 & 0.0017 & -0.0015 \\
\hline Ethnic origin & -0.0050 & -0.0039 & -0.0035 & -0.0048 & -0.0046 & -0.0052 & -0.0034 & -0.0051 & -0.0050 & -0.0054 \\
\hline Employment status & 0.0006 & -0.0008 & -0.0013 & -0.0020 & -0.0028 & -0.0033 & -0.0009 & -0.0003 & -0.0016 & -0.0008 \\
\hline Higher degree & 0.0018 & 0.0011 & 0.0031 & 0.0001 & -0.0005 & 0.0020 & 0.0040 & 0.0011 & -0.0020 & 0.0019 \\
\hline Marital status & -0.0042 & -0.0036 & -0.0036 & -0.0042 & -0.0038 & -0.0037 & -0.0039 & -0.0033 & -0.0037 & -0.0030 \\
\hline Year of interview & -0.0030 & -0.0019 & -0.0011 & -0.0019 & -0.0017 & -0.0013 & -0.0004 & -0.0021 & -0.0022 & -0.0013 \\
\hline Job tenure & -0.0213 & -0.0146 & -0.0130 & -0.0073 & -0.0103 & -0.0070 & -0.0121 & -0.0128 & -0.0173 & -0.0207 \\
\hline Ageband & -0.0209 & -0.0114 & -0.0139 & -0.0259 & -0.0293 & -0.0160 & -0.0162 & -0.0127 & -0.0352 & -0.0259 \\
\hline Occupation & 0.0095 & 0.0111 & 0.0166 & 0.0053 & 0.0054 & 0.0235 & 0.0141 & 0.0103 & 0.0115 & 0.0207 \\
\hline Industry & 0.0390 & 0.0326 & 0.0369 & 0.0265 & 0.0195 & 0.0315 & 0.0338 & 0.0324 & 0.0585 & 0.0324 \\
\hline Coefficient effect & 0.0811 & 0.0764 & 0.1486 & 0.1354 & 0.1656 & 0.2071 & 0.1458 & 0.1110 & 0.0728 & 0.0720 \\
\hline Ethnic origin & 0.0812 & 0.0507 & 0.0049 & -0.0392 & 0.0060 & 0.0047 & 0.0469 & 0.0608 & -0.0050 & -0.0228 \\
\hline Employment status & -0.0361 & -0.0090 & -0.0290 & -0.0237 & -0.0093 & -0.0221 & -0.0229 & -0.0089 & 0.0010 & -0.0343 \\
\hline Higher degree & -0.0059 & 0.0014 & -0.0026 & 0.0154 & -0.0064 & -0.0093 & 0.0207 & -0.0035 & 0.0022 & -0.0016 \\
\hline Marital status & -0.0158 & -0.0125 & -0.0202 & 0.0088 & -0.0160 & -0.0023 & -0.0253 & 0.0054 & -0.0038 & -0.0223 \\
\hline Year of interview & 0.0163 & -0.0092 & 0.0095 & -0.0059 & 0.0050 & 0.0095 & -0.0062 & -0.0107 & -0.0354 & -0.0094 \\
\hline Job tenure & -0.0052 & 0.0010 & -0.0004 & 0.0039 & 0.0004 & 0.0002 & -0.0022 & 0.0022 & -0.0051 & 0.0022 \\
\hline Ageband & 0.0289 & 0.0031 & 0.0058 & -0.0036 & 0.0076 & 0.0032 & 0.0047 & 0.0120 & 0.0088 & 0.0082 \\
\hline Occupation & -0.0254 & -0.0291 & -0.0232 & -0.0311 & -0.0278 & -0.0142 & -0.0106 & -0.0316 & -0.0272 & -0.0438 \\
\hline Industry & -0.0753 & -0.0678 & -0.0668 & -0.0271 & 0.0008 & -0.0923 & -0.0488 & -0.0773 & -0.1026 & -0.0677 \\
\hline Constant & 0.1185 & 0.1478 & 0.2706 & 0.2380 & 0.2054 & 0.3296 & 0.1896 & 0.1627 & 0.2402 & 0.2635 \\
\hline
\end{tabular}

